\title{
Incorporating the monolithic nature of paste backfill into self heating assessments
}

\author{
Chris Lee, Bret Timmis, David Brown \& Valerie Bertrand \\ Golder Associates Ltd. (Canada) \\ Matthew Stewart \\ Vale Newfoundland and Labrador Inc
}

SUMMARY: Tailings have exhibited self heating behaviour due to exothermic sulphide oxidation. Self-heating in paste backfill has caused dangerous temperatures and $\mathrm{SO}_{2}$ concentrations. Self-heating potential is commonly evaluated using a laboratory test in which heated air is forced through crushed material. However, due to the monolithic nature of backfill, including a very low permeability to oxygen and moisture, laboratory tests using a pulverized sample may be conservative and conducting tests with monolithic samples may be more representative. Field trials were conducted at Voisey's Bay Mine, Canada.

Keywords: Self-heating, tailings, sulphide, oxidation, geochemistry

\section{INTRODUCTION}

Mine tailings, ore, waste rock, and cemented paste backfill (CPB) have exhibited self-heating behaviour largely due to the exothermic oxidation of sulphide minerals, most notably pyrrhotite, with oxygen and water. The by-products of this reaction include heat and $\mathrm{SO}_{2}$ gas. The potential for self-heating in paste backfill has also been documented in several mines (Bernier and Li, 2003; Good, 1977; Fong et al., 2009; Nantel and Lecuyer, 1983; Patton, 1952) and has been seen to result in dangerous temperatures and $\mathrm{SO}_{2}$ gas concentrations which have affected production. Therefore, characterization of self-heating potential is an important component of mine planning with respect to health $\&$ safety as well as identification of risks to continuity of mine operations.

Presently, the potential for self-heating is typically evaluated using a laboratory scale test initially developed by Noranda (now Glencore), and then further refined at McGill University by Dr. Jan Nesset. Within this paper, this laboratory test procedure is referred to as the Noranda Test. The Noranda test uses a modified calorimeter apparatus and relies on the use of heated air which is forced through tailings that are at the worst-case moisture content for selfheating potential. The heat produced by the reaction of the tailings is measured and a comparison is made against a substantial database of other materials to assess the potential for self-heating. However, due to the monolithic nature of the paste backfill which includes a very low permeability to both oxygen and moisture it is intuitively expected that the Noranda test which uses a pulverized sample may be conservative and that conducting tests with monolithic samples may be more representative of the actual field conditions. Before investing billions of dollars of capital, mining companies require a high level of certainty regarding the potential for self-heating and its impact on mine production and safety and until such a test is 
available, the Noranda test is the best available method for determining self-heating potential. However, application of the Noranda test alone may result in overly conservative assumptions by mine developers with negative implications for mine economics.

Golder Associates Ltd. (Golder) was retained by Vale Newfoundland and Labrador Inc. (Vale) to evaluate the self-heating potential of paste backfill proposed for use in underground mine development, beginning with laboratory scale tests, which advanced to field scale tests upon identification of strong potential for self-heating in laboratory scale testing. This paper presents an evaluation of a new field-scale methodology for evaluation of self-heating potential of paste backfill alone or in conjunction with ore in order to provide a greater degree of certainty than the Noranda laboratory test alone. Field-scale testing was conducted at Voisey's Bay Mine, Newfoundland and Labrador, Canada.

\section{SELF-HEATING OF SULPHIDE BEARING MINE WASTES}

Sulphide mineral oxidation is an exothermic reaction. Pyrrhotite $\left(\mathrm{Fe}_{1-\mathrm{x}} \mathrm{S}\right)$ is of particular concern for self-heating due to its fast oxidation reaction rate upon exposure to air (oxygen) and moisture (20-100 times faster than pyrite) and the ability of pyrrhotite to self-heat on its own whereas other self-heating cases require a mix of sulphide minerals (i.e. pyrite and chalcopyrite, Wang, 2007). When pyrrhotite content is elevated or when pyrrhotite occurs with other sulphide minerals where galvanic interaction increases the oxidation rates, the heat generated by oxidation may not dissipate quickly enough and can result in self-heating (Wang 2007, Payant et al, 2012). Heat generation at a rate insufficient to overcome cooling by ambient air is not classified as self-heating. Pyrrhotite oxidation can generate elemental sulphur $\left(\mathrm{S}^{\circ}\right)$ that will oxidize into sulphur dioxide gas $\left(\mathrm{SO}_{2}\right)$ through direct oxidation reaction involving proton acidity $\left(\mathrm{H}^{+}\right)$:

$$
\begin{gathered}
\mathrm{Fe}_{1-\mathrm{x}} \mathrm{S}+(1-\mathrm{x}) / 2 \mathrm{O}_{2}+2(1-\mathrm{x}) \mathrm{H}^{+}=(1-\mathrm{x}) \mathrm{Fe}^{2+}+\mathrm{S}^{\mathrm{O}}+(1-\mathrm{x}) \mathrm{H}_{2} \mathrm{O}(\text { with } \mathrm{x}=0.1) \\
\mathrm{S}^{\mathrm{O}}+\mathrm{O}_{2}=\mathrm{SO}_{2}
\end{gathered}
$$

Alternatively, hydrogen sulfide gas $\left(\mathrm{H}_{2} \mathrm{~S}\right)$ can be generated through an oxidation reaction involving $\mathrm{H}^{+}$:

$$
\mathrm{Fe}_{1-\mathrm{x}} \mathrm{S}+\mathrm{H}^{+}=(1-3 \mathrm{x}) \mathrm{Fe}^{2+}+2 \mathrm{xFe}^{3+}+\mathrm{H}_{2} \mathrm{~S}(\text { with } \mathrm{x}=0.1)
$$

Several papers have reported self-heating events leading to $\mathrm{SO}_{2}$ emissions in underground mines. Some of them identified backfill as the source (Bernier and Li, 2003; Nantel and Lecuyer, 1983; Patton, 1952) and some discussed ore as the source (Good, 1977; Fong et al., 2009). The purpose in reporting these papers is to highlight that self-heating events have occurred in the past with backfill containing pyrrhotite, sometime cemented and sometimes not. Bernier and Li (2003) presented the results of three case histories where highly oxidized CPB samples were recovered underground at two mines in northern Quebec and one mine in New Brunswick. The less oxidized, green-greyish paste reacted at temperatures less than $100{ }^{\circ} \mathrm{C}$ and did not emit $\mathrm{SO}_{2}$. The more oxidized, orange to red paste reached the temperature range of $250-400{ }^{\circ} \mathrm{C}$ and emitted $\mathrm{SO}_{2}$ during its oxidation process.

Patton (1952) reported heating of underground backfill made of $75 \%$ of crushed reverberatory furnace slag ( 0 to 4 inches) and $25 \%$ pyrrhotite at Noranda mine. Top stope backfill reached $87^{\circ} \mathrm{C}$ while centre and bottom reached respectively $204^{\circ} \mathrm{C}$ and $68^{\circ} \mathrm{C}$; occasional odour of $\mathrm{SO}_{2}$ in underground mine was also reported. Fong et al. (2009) reported in an internal memorandum a CPB self-heating event at Brunswick mine occurred in 2008. CPB used at this time at Brunswick contained $57.1 \%$ pyrite and $1.0 \%$ pyrrhotite and achieved $1 \mathrm{MPa}$ at 28 days with $5 \%$ wt. of T50 cement. For that case, the CPB in and/or around the muck fire stope was 
deemed unlikely to be the source of self-heating initiation. However, the paste fill present in this stope contributed to $\mathrm{SO}_{2}$ emission once the self-heating process was taken beyond the ignition temperature of about $350-400{ }^{\circ} \mathrm{C}$ for pyrite.

$\mathrm{CPB}$ is generally considered to have reduced self-heating potential as compared to the source ore, tailings, or waste rock. The addition of cement and binder supports the formation of a low-permeability monolith with added neutralisation capacity to prevent mobilisation of acidity generated through sulphide oxidation.

\section{SITE CHARACTERISTICS}

The Voisey's Bay Underground Mine project is expected to contain a very high level of pyrrhotite content in the ore (66 to 72\% in high-grade ore, [Golder 2018a, Golder 2018b]). As part of development of underground operations, Vale proposes to use milled tailings from the processing of underground ore to generate $\mathrm{CPB}$ to place in mined out stopes for underground structural support and improved ore recovery. This approach will also serve to minimise the surface disposal of the potentially acid-generating tailings.

Milled tailings contain high pyrrhotite contents (32-75\%, [Golder 2018a, Golder 2018b]) remnant from processed ore. Cement and slag binder (10\% normal Portland cement and 90\% ground granulated blast furnace slag, respectively) is to be added to CPB to provide strength and to help control self-heating reactions. The addition of cement adds neutralisation capacity to the reactive tailings while the hydration products of the binder that partially coat the tailings can reduce the effective permeability and increase the water retention capacity of the CPB and thus limit the ability of oxygen to penetrate into the CPB mass and to perpetuate the oxidation reactions. These factors are expected to help control the oxidation of pyrrhotite, limit self-heating and the subsequent generation of acid rock drainage (ARD).

During engineering design studies, laboratory tests were completed to assess the self-heating capacity of CPB with $2 \%$ to $4 \%$ binder content, as discussed in Golder (2017). The samples were prepared by crushing, drying, and re-crushing and grinding the cured paste cylinders; determination of self-heating capacity was conducted as described in Nessetech (2018). These test results indicated that CPB with $2 \%$ binder had a propensity for self-heating and therefore were not recommended for backfill, while CPB samples with $4 \%$ binder were not anticipated to self-heat. However, an increase in binder content from $2 \%$ to $4 \%$ would have implications on mine economics. Golder (2017) identified that the Noranda test may be overly conservative because it does not account for the properties of the CPB as planned to be placed in underground development at Voisey's Bay, which will consist of a water saturated monolith where oxidation reactions will be limited to surfaces exposed to air. Further studies were recommended to evaluate the self-heating potential of CPB with $2 \%$ binder at field-scale.

\section{METHODOLOGY}

\subsection{Design overview}

The test cells were designed to simulate a monolithic mass of CPB that would more closely resemble a backfilled underground stope but in a controlled, above ground setting. CPB and ore were placed in shipping containers (hereafter referred to as "test cells"). The test cell was selected to allow testing of a suitably large monolithic specimen of CPB and allow the installation of required instrumentation and equipment to control the temperature and moisture conditions. To evaluate sensitivity of the test materials and align with evaluation techniques employed in the Noranda test, the test concept was to heat the test cells to create conditions favourable to the development of self-heating. This method is meant to accelerate the selfheating reaction pathway and permits evaluation of self-heating potential over a practical period of time. 
Each test cell was instrumented with sensors to monitor oxygen, sulphur dioxide, temperature, and humidity. Humidity was controlled by a mister system which sprayed water (as mist) into the cell at multiple locations. The mister system was controlled by an automatic timer to activate it at pre-set intervals, with user intervention as needed to increase or decrease activation frequency based on monitoring data. Temperature was controlled by a heating and ventilation system with a user-adjustable thermostat. The thermostat was adjusted as necessary to align with planned heating cycles as described in Section 4.3. Sulphur dioxide and oxygen were monitored to identify geochemical reactions potentially indicative of self-heating. Sensor data from all test cells were recorded and stored in data loggers in an adjacent shipping container used as a field office for the test. The $\mathrm{SO}_{2}$ sensors used have a sensitivity of $0.6 \mathrm{ppm}$. Bernier and $\mathrm{Li}$ (2003) reported an odour threshold of 3-5 ppm for $\mathrm{SO}_{2}$. Newfoundland \& Labrador prescribes short-term occupational exposure limits (OEL-STEL) of $0.25 \mathrm{ppm} . \mathrm{O}_{2}$ sensors used have a sensitivity of $0.5 \%$.

The test design intended to replicate as accurately as possible the anticipated conditions in an underground stope. However, the following characteristics could not be fully represented:

1) Underground mining at Voisey's Bay has not commenced and as such the volumes of tailings and ore required for the test were not available from underground sources. However, geochemical and mineralogical evaluation of ore performed by Voisey's Bay staff from the presently mined Ovoid Pit have demonstrated these characteristics to be similar to those of rock from exploration core from the underground development zones. As a result, ore and tailings derived from present operations in the open pit were used in the self-heating tests.

2) Underground temperature and humidity are expected to be variable inside the mine. According to current knowledge on self-heating, the test aimed at creating an environment that would promote self-heating (i.e. higher temperatures than expected inside the mine) and measure the reaction.

3) An underground stope is larger than the test cells. However, the spatial dimensions of the test CPB is considered to be adequate to represent surface interactions.

4) Variability in cement content of the CPB. Testing was performed with $2 \%$ cement (Table 1 ) representative of the current $\mathrm{CPB}$ recipe. If cement content is decreased, the behaviour may be different than that described in this paper.

5) Variability of the tailings and ore sulphide content. Behaviour observed is strongly related to materials used and cannot account for variability over the time. Especially for tailings, particle size is an important parameter of oxygen diffusion behaviour and a change would involve a different performance for the backfill than that described in this paper.

6) As observed in the memorandum of Fong et al. (2009), explosives can be an ignition source of self-heating. This aspect was not part of the testing program.

\subsection{Test cell preparation}

The current study was conducted prior to construction of an on-site paste plant. As an alternative, paste was prepared in the mill by pumping fresh tailings into a concrete ready-mix truck. Some variability in paste composition is a potential result of the time between collection of tailings for each test cell; although not known at the time of paste preparation, notable differences in paste composition (specifically sulphide content) were identified through laboratory testing and are discussed in Section 5.2. The mixing truck drum was filled with tailings

Table 1. Masses applicable to binder addition.

\begin{tabular}{llllll}
\hline Cell \# & Content & CPB curing time & Tailings dry mass (kg) & Binder mass (kg) & Binder (\%wt.) \\
\hline Cell 1 & CPB only & 31 days (28 planned) & 8,970 & 183 & $2 \%$ \\
Cell 2 & CPB and ore & 28 days & 15,548 & 317 & $2 \%$ \\
Cell 3 & CPB and ore & 19 (14 planned) & 16,768 & 342 & $2 \%$ \\
\hline
\end{tabular}


and allowed to settle. After settling, water above the tailings was removed, and the space previously occupied by water was filled with fresh tailings. This process was repeated until the drum was more than $90 \%$ full of tailings and paste technical parameters (moisture content and slump) were achieved. The required binder mass was calculated and added to the drum (Table 1). The drum was rotated for a minimum of one hour to fully mix binder and tailings to produce paste. The paste was then poured into lined formwork in the test cell, the cell was closed, and the curing period initiated. Paste in each test cell was permitted to cure in a closed environment for the period of time defined in Table 1; curing time was varied between Cells 2 and 3 to evaluate if curing time affected the development of self-heating.

Following completion of the curing period, the test cells were opened, formwork was removed, and ore was placed beside and in direct contact with the paste (Cells 2 and 3 only). Cell 1 is intended for the purposes of this evaluation to be a "control" cell, to evaluate the potential for self-heating conditions in the paste alone without the presence of ore. Ore was sourced from the Ovoid Pit stockpile, not screened but coarse particles were rejected when sampled with the result of having a wide particle size distribution from zero to approximately $200 \mathrm{~mm}$. Subsequently, ore was stored under a tarp near the test cells for 4 weeks, until the time to be placed in contact with the CPB by a backhoe. The volume of ore added to Cell 2 and Cell 3 was similar (+/- 15\%) to the volume of paste; however, the mass was not recorded. At the time of placing the ore in the test cells, visible ore oxidation was minimal to absent. The test cells following completion of construction and paste placement are shown in Figure 1. Only the three left cells were used for testing; the fourth cell was compromised and not included in the test.

\subsection{Test operation}

The test was conducted as per the dates presented in Table 2. Sensor data was logged continuously and evaluated for indications of self-heating throughout each day.

Over the evaluation period, each cell was submitted to nine heating periods of 24 hours. During heating cycles, the heater unit was activated to reach the target temperature, monitored via internal sensors (Figure $2 \&$ Figure 3). Once the target temperature was reached the temperature was maintained for 24 hours after which the heater unit was turned off for 24 hours. Following the 24-hour no-heat period, the next heating cycle began. For the first three

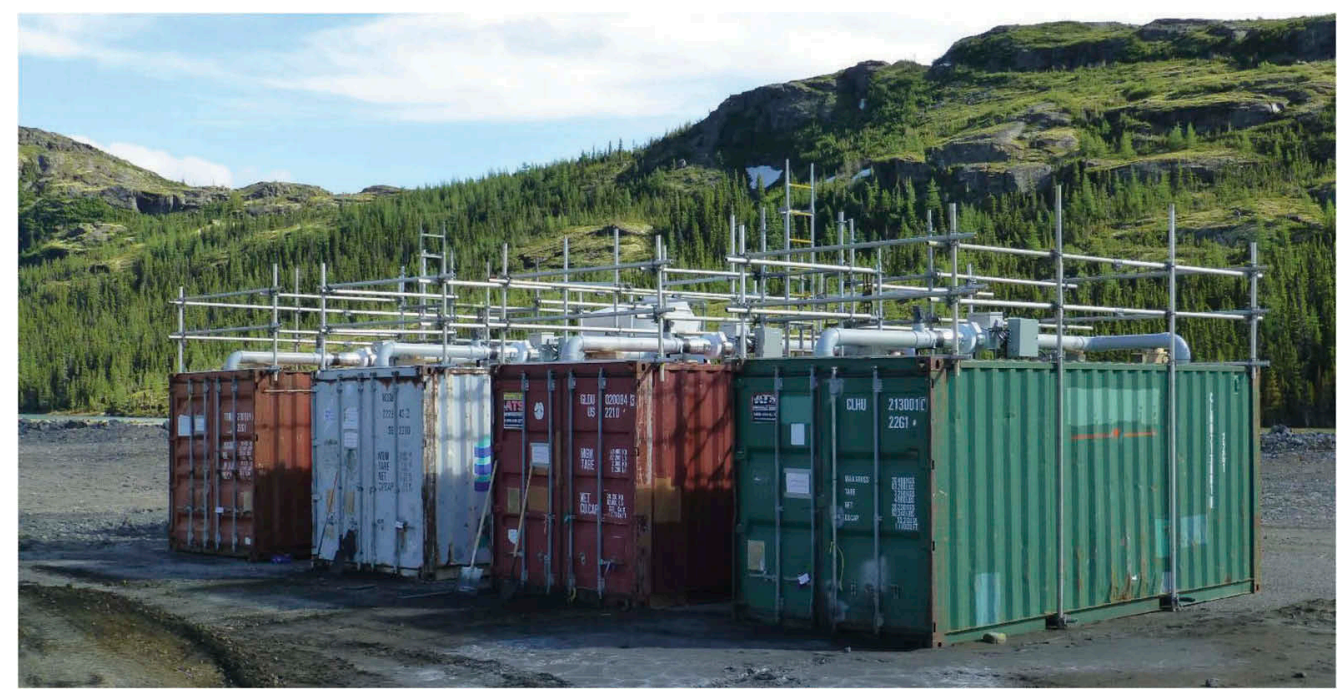

Figure 1. External photograph of test cells. 
Table 2. Testing phases.

\begin{tabular}{llll}
\hline Event & Cell 1 & Cell 2 & Cell 3 \\
\hline CPB poured & June 11, 2018 & June 14, 2018 & June 22, 2018 \\
Ore placement & N/A & July 12, 2018 & July 12, 2018 \\
Start of test (no heat) & & July 12, 2018 & \\
Initiation of heating cycles & & July 18, 2018 & \\
End of heating cycles & & August 8, 2018 & \\
End of test & & August 28, 2018 & \\
\hline
\end{tabular}

heating cycles, the target temperature was $40{ }^{\circ} \mathrm{C}$. The remaining 6 heating cycles were operated to reach the maximum temperature possible via throughput of the heater $\left(45\right.$ to $55^{\circ} \mathrm{C}$ inside air temperature), with this temperature limit influenced by external climate.

The heating cycle from July 25th through 29 th was extended to determine if running the heater for an extended period would permit reaching higher air temperatures (the finding was that the extended operation did not yield higher air temperatures than normal cycle durations, and the delayed peak during this period is due to low outside air temperatures). The objective of these temperature increase time periods was to generate favourable conditions for selfheating (high temperature, high humidity, and presence of ore in contact with the paste). It should be noted that the maximum temperatures tested are beyond maximum safe temperatures for an underground mine work environment; however, the higher temperatures were used to promote reactions which may lead to self-heating. Relative humidity inside the test cells was targeted to be in a range $80-90 \%$ over the testing period using automatic sprayers to represent the underground mine environment.

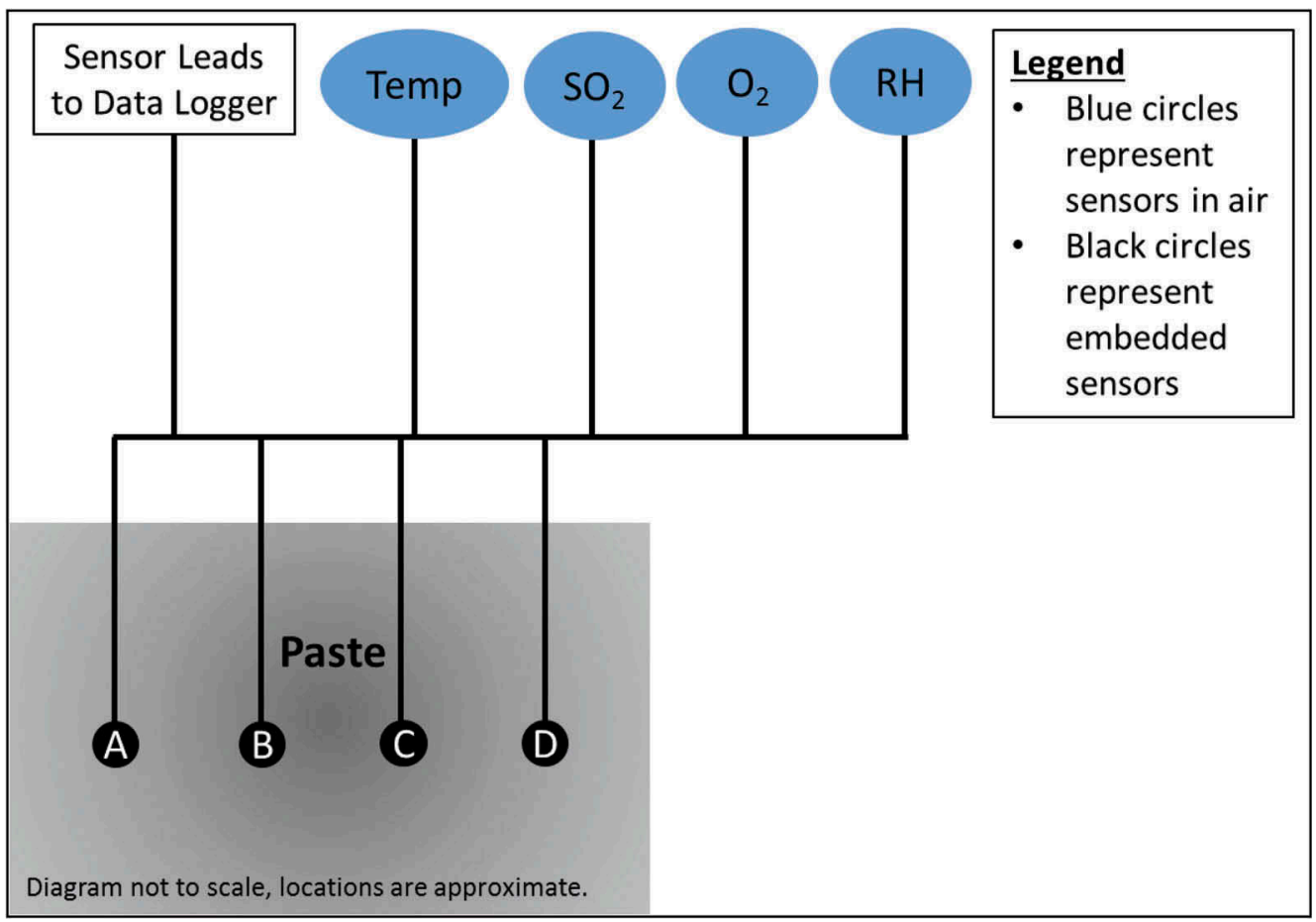

Figure 2. Schematic of sensor locations in cell 1. 


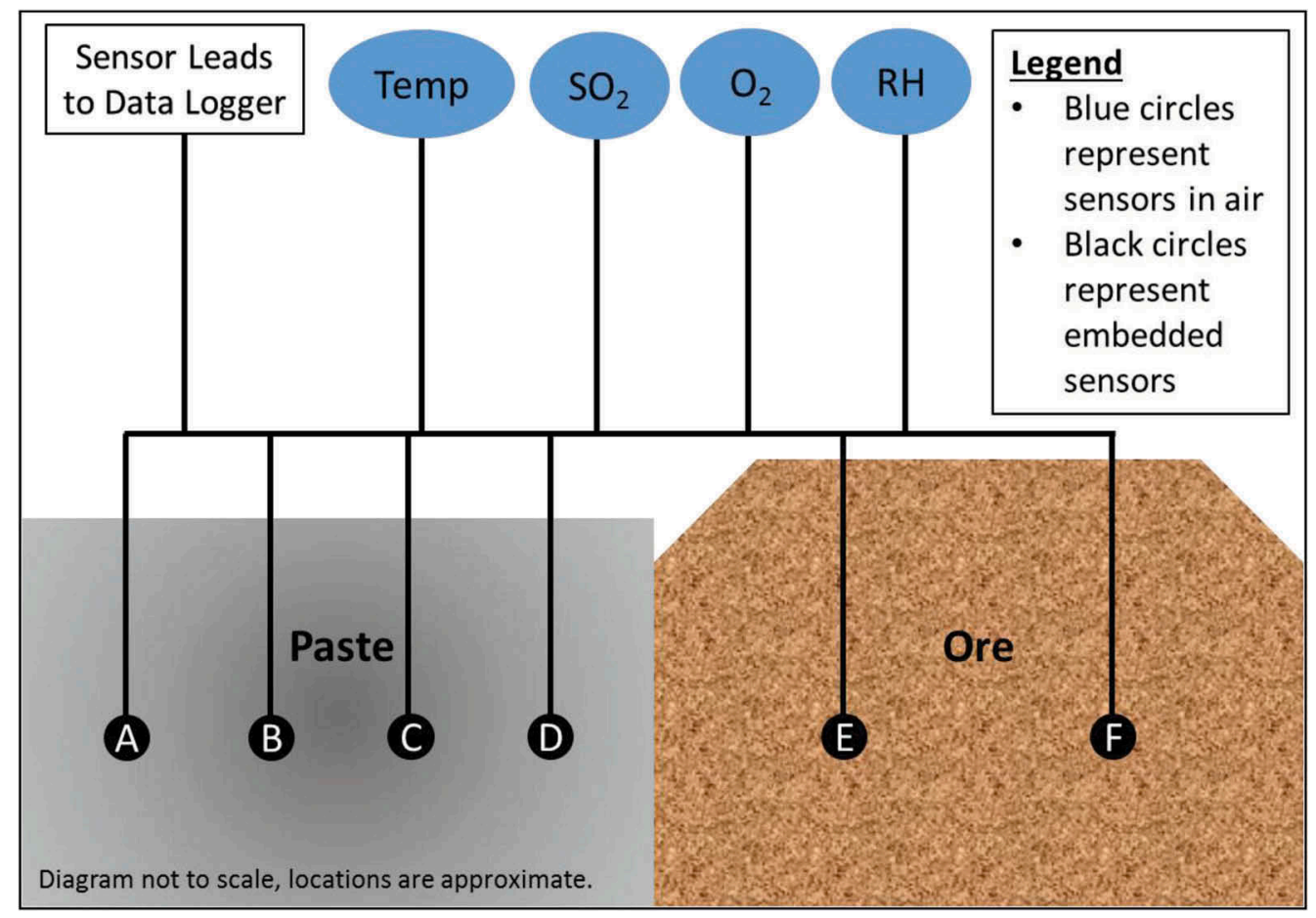

Figure 3. Schematic of sensor locations in cells 2 and 3.

\section{RESULTS}

\subsection{Test cell instrumentation results}

Instrumentation measurements were recorded from the start of test (July 12) to end of test (August 28, 2018), monitoring temperature, oxygen, sulphur dioxide, and relative humidity. Sulphur dioxide measurements were within the standard error of the sensor at all times during the test. Accordingly, these values are not discussed further and are inferred to indicate that no appreciable generation of sulphur dioxide occurred. At the initiation of the test period following removal of formwork (all cells) and placement of ore (Cell 2 and Cell 3), no notable changes in temperature, oxygen, or relative humidity were observed; temperature changes noted are attributed to external (natural) variation in air temperature. Therefore, discussion of instrumentation results is focussed upon the period from initiation of heating (July 18th, 2018) to the end of the test (August 28th, 2018).

\subsubsection{Temperature}

Temperature results are presented graphically in Figure 4 and Figure 5, with statistics in Table 3 . Figure 4 permits evaluation of relative changes in air temperatures inside each cell and outside air temperatures. Outside air temperatures influence internal (inside cell) air temperatures, particularly when heating is not activated, and also as a control on the upper limit of inside air temperatures during heating. Figure 5 presents internal paste and ore temperature results for each temperature sensor, showing differences with respect to sensor location and differences between each cell.

Based on the results presented in Figure 4 and Figure 5, activation of the heater is the primary control upon internal air, paste, and ore temperatures. The secondary control is external air temperatures in the natural environment. At the end of the heating cycles through to the 


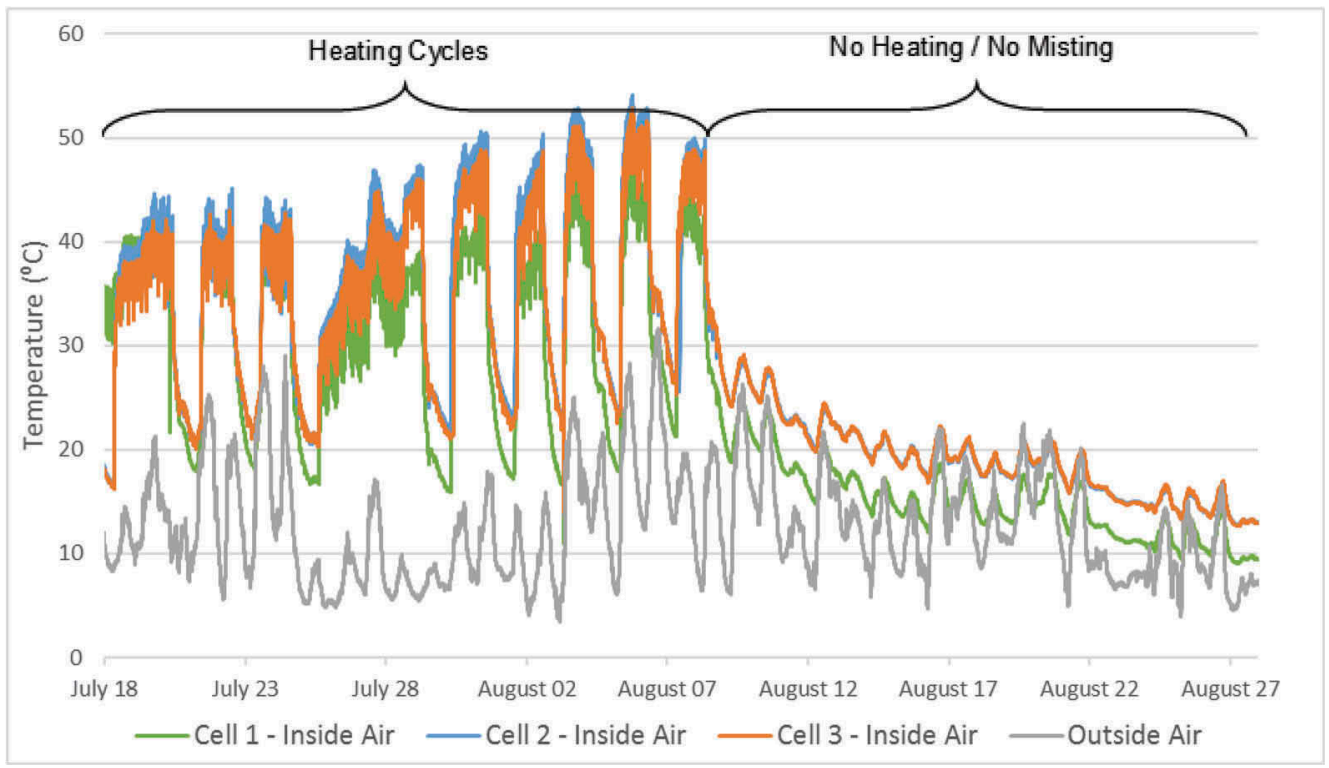

Figure 4. Temperature of air inside test cells and outside air temperature.

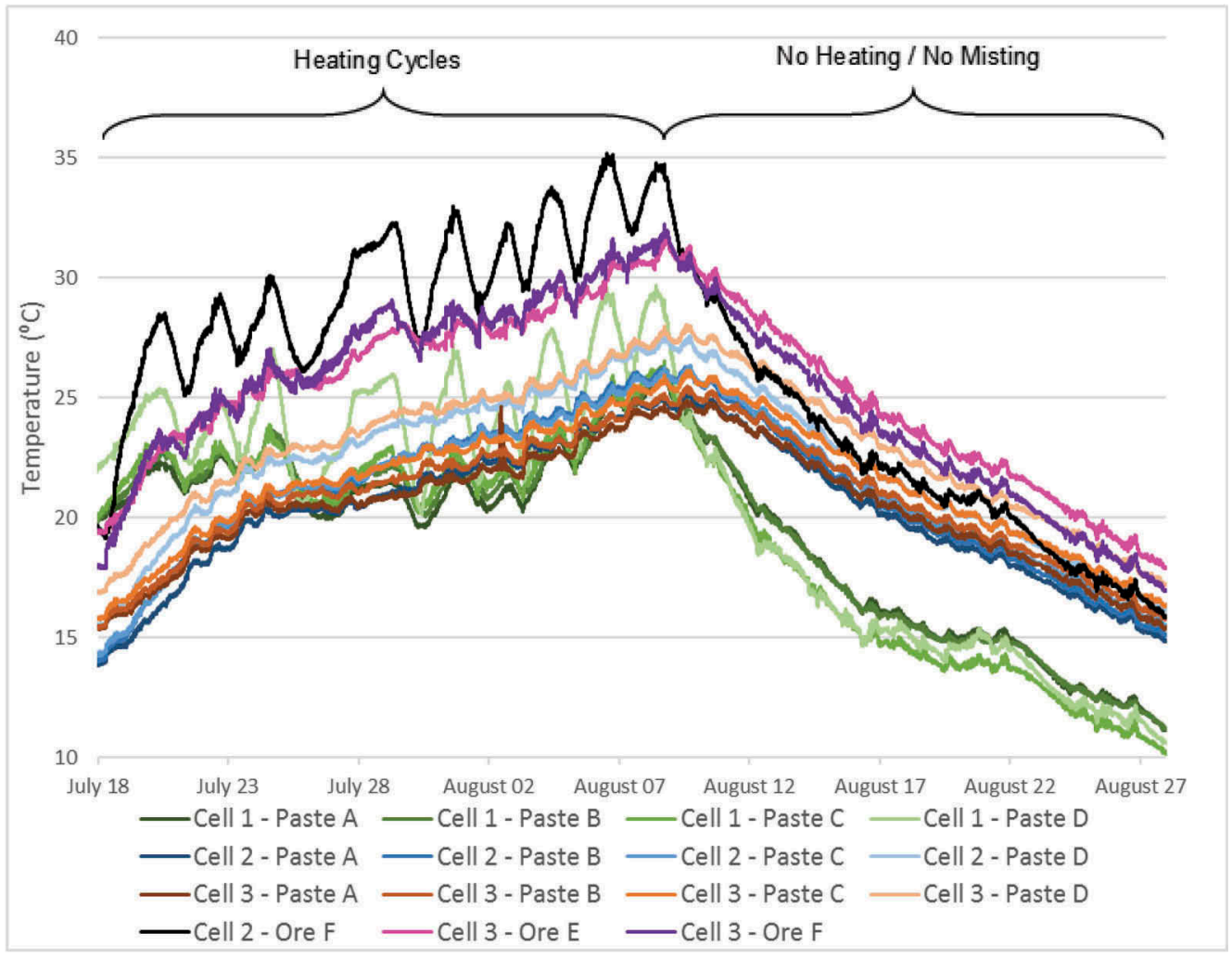

Figure 5. Temperatures reported by sensors embedded in paste and ore (locations described in Figure $3)$. A to $\mathrm{F}$ refer to sensor location. 
Table 3. Range of measured air temperatures over the test period $\left({ }^{\circ} \mathrm{C}\right)$ after initiation of heating.

\begin{tabular}{lccll}
\hline & Outside Air & Cell \#1 & Cell \#2 & Cell \#3 \\
\hline Minimum & 3.4 & 9.1 & 12.7 & 12.6 \\
Average & 12.5 & 23.9 & 28.0 & 27.6 \\
Maximum & 31.6 & 47.8 & 54.1 & 52.9 \\
\hline
\end{tabular}

end of the test, a steady decrease in temperatures is observed, with minor increases in temperature aligned directly with instances of higher external air temperatures (Figure 4). During periods when the heater is not active, changes in internal cell temperatures are directly relatable to external air temperatures and sunlight on test cells. Temperatures in Cell 1 generally exhibited greater variability and lower values than in the other cells; this is interpreted to be primarily due to the lack of insulating effect from ore. It is possible that heat generated by oxidation of ore contributed to higher temperature values but if so, the effect was insufficient to overcome passive cooling during the no-heat periods. Because the sidewall of the paste in Cell 1 is in direct contact with air, the paste temperature at that location changes more rapidly.

No evidence exists for sustained increases in temperature other than as a direct result of heating applied intentionally in the test procedure. If any heat was generated from sulphide oxidation, it occurred at an insufficient rate to overcome cooling towards ambient conditions during no-heat periods.

\subsubsection{Oxygen}

Relative humidity and oxygen inside the test cells were influenced by operation of the heating and ventilation unit which introduced outside air to each cell when active. Evaluation of results from the three test cells (Figure 6) indicates that relative humidity decreases when internal temperature increases (ventilation blows out humidity) while $\mathrm{O}_{2}$ increases (ventilation brings fresh air). Analysis of recorded oxygen concentrations (Figure 6) do not show evidence of sustained consumption of oxygen from oxidation of sulphides (and potential self-heating) during any phase of the test. The test cells are not airtight and ingress of oxygen over time is expected even while the cells are sealed. The cause of increased variability in Cell 2 results is unclear and potentially related to inconsistency in the sensor given the lack of correlating changes in any other parameters. Cell 3 results are interpreted to be lower due to a calibration error but appear to be consistent with Cell 1 over time.

\subsubsection{Relative humidity}

From the complete dataset recorded, relative humidity data ranged between $19.2 \%$ and $99.9 \%$ (Figure 7). The relative humidity inside the test cells was targeted to be in the range of $80-90 \%$ over the testing period using automatic sprayers to represent the underground mine environment; however, when the heating and ventilation unit was active, added humidity was quickly lost and the high humidity was not maintained, while excess humidity was present when the heating and ventilation was not active. Actual moisture content of paste was assumed to be at a higher level than heated air due to ingress of water during high humidity periods which would not be withdrawn from paste during the 24-hour heating cycles. This assumption was confirmed during the post-test visual inspection which determined that the first $1 \mathrm{~cm}$ of paste was unsaturated, while all paste beyond $1 \mathrm{~cm}$ depth was water saturated.

Cell 1 generally was observed to have the highest humidity values, which may be due to quicker settling of the mist in the space next to the paste, whereas in the other cells, airborne water could only circulate in the limited headspace above both paste and ore resulting in increased loss through ventilation. Cell 2 generally has higher humidity values than Cell 3; paste and ore placement is the same in both cells and there is no clear driver for this variation. 


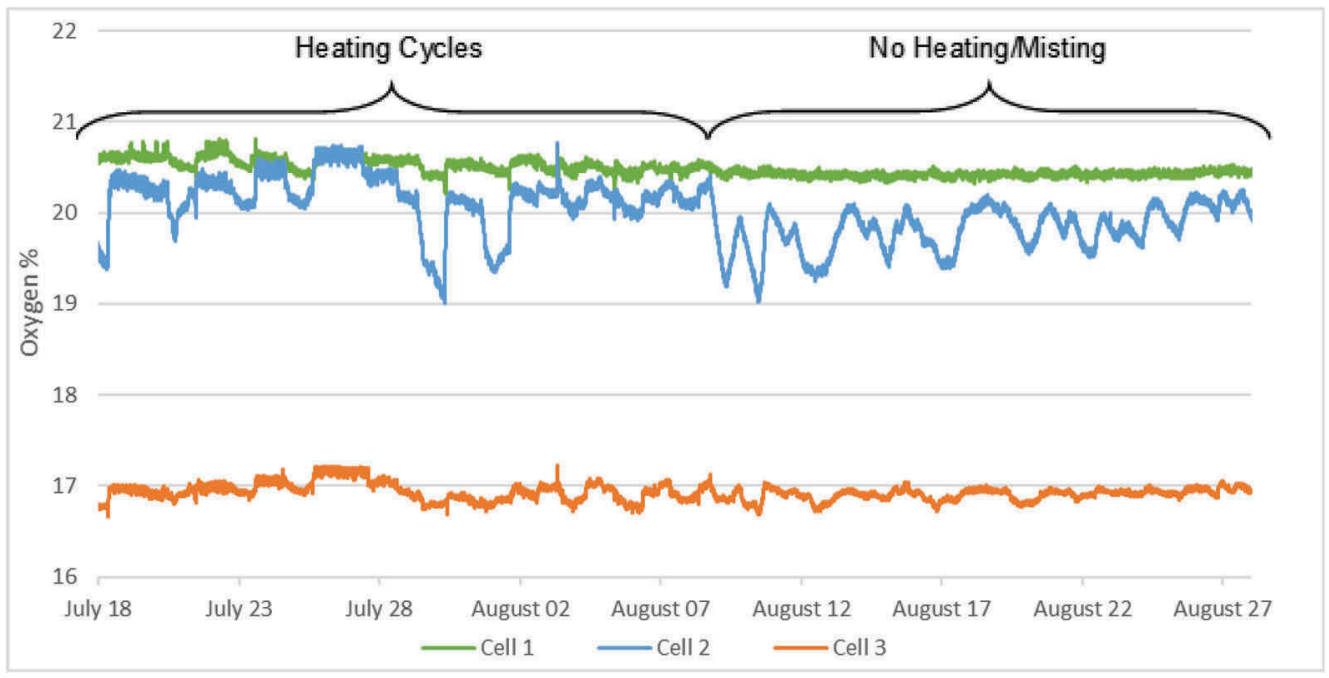

Figure 6. Oxygen content over evaluation period.

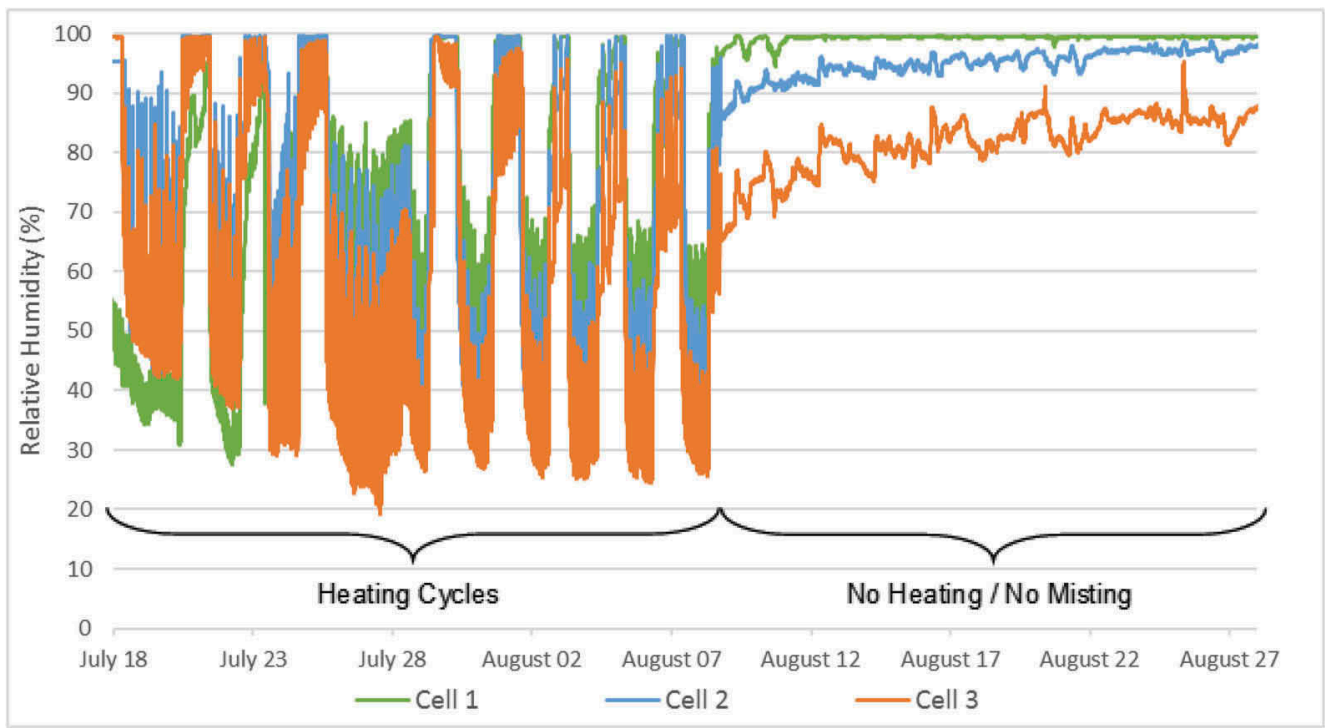

Figure 7. Relative humidity over evaluation period.

\subsection{Mineralogical and geochemical results}

Prior to the initiation of testing, samples of ore and wet paste were collected for geochemical and mineralogical analysis. Samples collected following completion of the field test were submitted for the same analyses. Pre-test results are used to confirm the test materials are consistent with expected characteristics for paste backfill underground at Voisey's Bay, and as a baseline reference for post-test samples. Post-test paste samples were collected at surface $(<1 \mathrm{~cm}$ depth) to $75 \mathrm{~cm}$ depth from the closest edge of the paste block to evaluate changes in geochemical and mineralogical composition resulting from the field test. Results for selected parameters of interest are summarized in Table 4. 


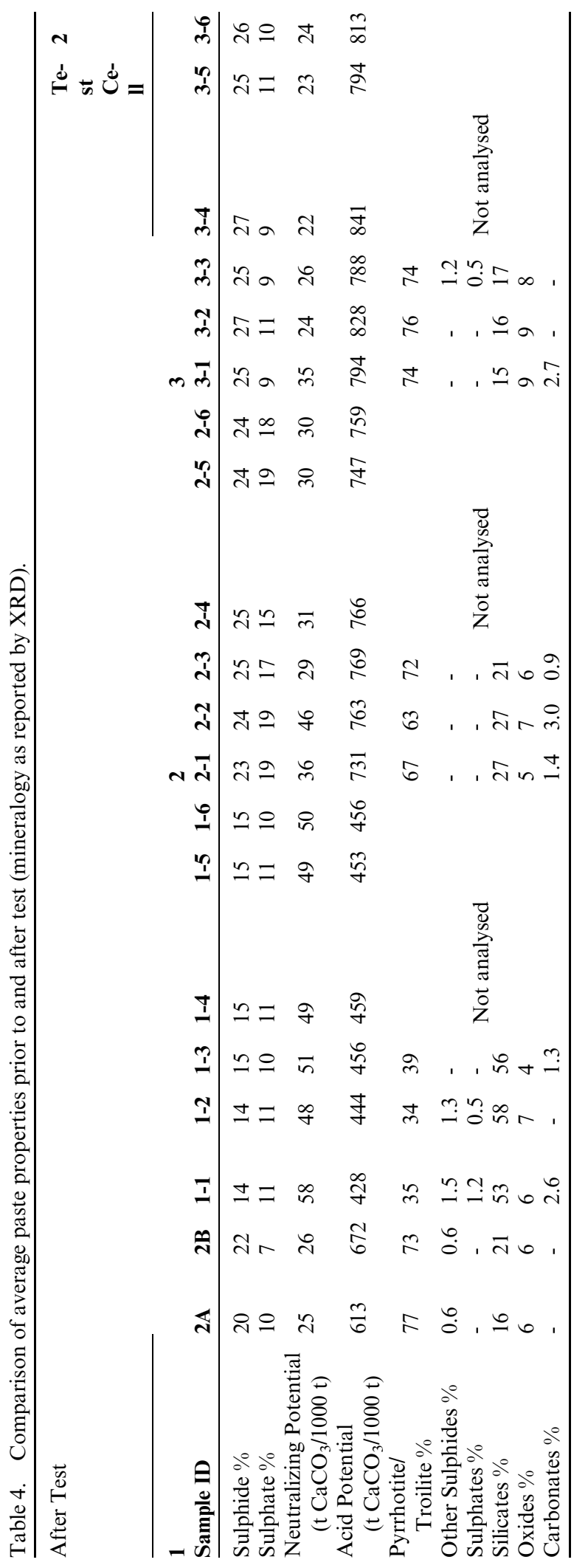


Table 4 indicates some differences in geochemical and mineralogical characteristics for post-test samples collected from Cell 1 as compared to samples from Cell 2 and Cell 3. No pre-test samples were analysed from paste used in Cell 1 for comparison. Cell 1 samples have lower abundance of sulphide minerals and greater abundance of silicate minerals than Cell 2 and Cell 3. Because this change in mineral composition cannot occur simply as a transformation during the test, heterogeneity in the tailings feed from the mill at the time of preparation is the probable cause. Surface shavings samples (VB2-2, VB3-1) which were anticipated to potentially demonstrate stronger effects from testing due to directly exposed surface area, did not yield any notable differences compared to samples collected at greater depth. It is important to consider that some extent of sample heterogeneity is expected and that small variations in results (i.e. relative percent difference less than $20 \%$ ) may not be indicative of any trends.

\subsection{Visual inspection of test cells after termination}

Following the completion of the field test, a visual inspection of the test materials was undertaken to identify any evidence of test related effects (Figure 8). In both Cell 2 and Cell 3, ore was observed to have taken a reddish tarnish, indicating that surficial oxidation of the sulphides had occurred. In contrast, paste showed no evidence of evolution over the testing period and no oxidation products were evident. Two samples of isolated white precipitate were selected for a targeted QEMSCAN analysis. Results of this analysis found that in one case this material was comprised of calcite, while in the other case the precipitate was no longer visible, but a cementing material comprised of calcite and gypsum was observed. Calcite is likely derived from lime and/or cement binder addition, while gypsum is a common precipitate following sulphide oxidation. The constituents required for gypsum precipitation were likely present in the paste prior to pouring and may not represent additional sulphide oxidation during testing. Regardless, the volume of precipitate observed was extremely small and not representative of bulk characteristics of the paste. Paste was water saturated at shallow depth (less than $1 \mathrm{~cm}$ from surfaces), and no defined crust was present. The paste appearance was uniform across horizontal and vertical position.

\section{DISCUSSION}

Key findings of the test cell monitoring results can be summarized as follows:

- Paste and ore temperatures rose during heating periods, and fell during all periods when heating was not active;

- Sulphur dioxide values were not detected above minimum sensor sensitivity at any time;

- Oxygen was not consumed at a rate to indicate rapid oxidation reactions and self-heating; and

- If heat was generated from sulphide oxidation, it occurred at an insufficient rate to overcome cooling towards ambient conditions during no-heat periods.

The test results indicate that sulphide oxidation over the test period was primarily limited to ore, with no evidence of oxidation in CPB. Self-heating conditions (generation of heat at a rate sufficient to overcome cooling with ambient air during no-heat periods) were not observed through any of the measurements made during and after the test. Visual inspection of the CPB determined that it was water saturated, which is an important characteristic for the prevention of sulphide oxidation and therefore self-heating.

The test results indicate that $\mathrm{CPB}$ with $2 \%$ binder did not develop significant self-heating conditions in the field test cells, given that paste and ore temperatures fell during all periods where the external heat source was no longer applied. All instances of increasing paste and ore temperatures can be directly related to elevated ambient air temperatures, either due to activation of the heating unit or due to external (natural) temperature increase. The tailings and the 


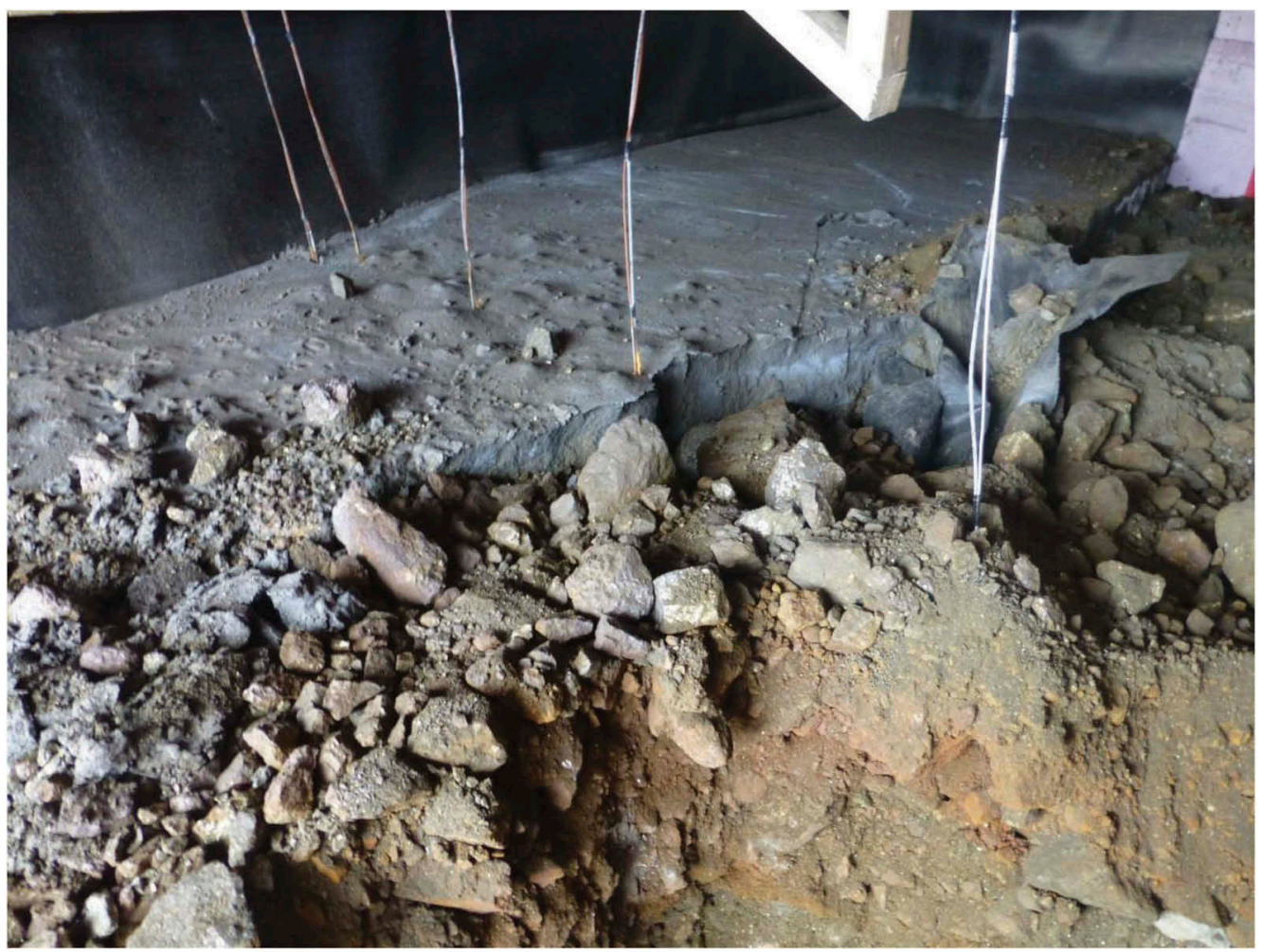

Figure 8. Cell 2 paste with partially excavated ore.

addition of the binder are favourable for maintaining high water saturation in paste pore space that in turn limit oxygen diffusion. The test was designed as an analogue to underground paste backfill; however, the test cells are not a perfect representation of the underground environment due to factors including, but not limited to the following:

- Duration of testing (shorter than underground exposure);

- Differences in ventilation and ambient humidity and temperature;

- Presence of ore likely to occur on multiple sides of the paste in underground development rather than only one side in the test cells;

- Blasting (heat generated by blasting) conducted adjacent to paste in underground development;

- Minor differences in mineralogy and geochemistry of paste derived from underground ore compared to ore derived from the open pit used in the test cell; and

- Differences in paste preparation procedure (batches produced in a mix truck for test cells vs. continual production in a paste plant for underground use).

\section{CONCLUSIONS}

Field study results indicate that the potential for self-heating of the CPB under evaluation in this study was low under the study test conditions. This finding is in conflict with previous laboratory scale testing completed (i.e. The Noranda Test), which indicated high potential for the development of self-heating conditions in the materials tested. Therefore, evidence from the present study supports the hypothesis that laboratory scale testing of pulverised material 
may be overly conservative relative to actual conditions. Long-term monitoring of full-scale paste backfill deposition is required to validate this hypothesis.

The unique composition of minerals present at any given site may result in different outcomes than those described herein. Regardless of further refinement and validation of the procedures described in the current study, laboratory scale testing methods are anticipated to remain as important preliminary screening tools to determine whether additional study is required. However, the current findings suggest that laboratory scale test results of selfheating should not be relied upon in isolation to determine that an increased binder content is required to prevent the development of self-heating. Rather, the proponent should review the potential for field-scale testing to identify a lower binder content relative to long-term costs of increased binder content. If field-scale testing is deemed a desirable approach to evaluate whether binder content can be reduced, the proponent should engage with qualified experts in mine backfill technology and sulphide geochemistry.

\section{ACKNOWLEDGEMENTS}

Golder Associates Ltd. appreciates the support of Vale Newfoundland and Labrador in sharing the results of this innovative field trial with the scientific community and advancing the body of knowledge in the field of self-heating.

\section{BIBLIOGRAPHY}

Bernier, L. R., and Li, M. 2003. High temperature oxidation (heating) of sulfide paste backfill: a mineralogical and chemical perspective. [In:] Proceedings of Sudbury Mining and the Environment Conference.

Fong et. al. 2009 - Fong, G., Isagon, I., Lebonté, G., and Wheeler, R. 2009. Self-Heating Issues due to Oxidation of High-Sulphide Content in Ore, Waste and Paste Backfill, Notes from the Site Visit Conducted at Brunswick Mine and Smelting, Bathurst, NB, on Dec. 17-18, 2008.

Golder, 2017. Voisey's Bay Underground Mine - Self-Heating of Cemented Paste Backfill. Report prepared for Vale Newfoundland and Labrador. Project No. 1665718.

Golder, 2018a. Voisey's Bay Mine - Evaluation of Tailings Self-Heating Properties. Report prepared for Vale Newfoundland and Labrador. Project No. 1665718.

Golder, 2018b. Voisey's Bay Self-Heating Evaluation - Field Scale Trials. Report prepared for Vale Newfoundland and Labrador. Project No. 1665718.

Good, B.H. 1977. Sulphide Fires - The "Hot Muck" Problem, The Oxidation of Sulphide Minerals in the Sullivan Mine, CIM Bulletin, June 1977.

Nantel, J. and N. Lecuyer. 1983. Assessment of slag backfill properties for the Noranda Chadbourne Project Noranda, Quebec, CIM Bulletin, V. 76, No. 849.

Nessetech, 2018. Self-Heating Tests - Vale Voisey's Bay Samples. Report prepared for Golder Associates Ltd.

Patton, F. E. 1952. Backfilling at Noranda. Canadian Institute of Mining \& Metallurgy Transactions, V. 55 , pp. $137-143$.

Payant, R., F. Rosenblum, J.E. Nesset, J.A. Finch. 2012. The self-heating of sulphides: galvanic effects. In Minerals Engineering. Volume 12, p 57-63.

Wang, X. August 2007. Exploring Conditions Leading to Self-Heating of Pyrrhotite-Rich Materials. A thesis submitted to McGill University in partial fulfilment of the requirements of the degree of Master of Engineering. 